\title{
PENINGKATAN KEMAMPUAN PEMAHAMAN KONSEP MATEMATIS SISWA MELALUI MODEL PEMBELAJARAN KOPERATIF TIPE MAKE A MATCH
}

\author{
Budi Oktaviandi $^{1}$, Beni Junedi ${ }^{2}$, Mohamad Bayi Tabrani ${ }^{3}$ \\ ${ }^{1}$ Pendidikan Matematika STKIP Insan Madani Airmolek Kab. Indragiri Hulu Riau \\ ${ }^{2}$ Pendidikan Matematika Universitas Bina Bangsa Kota Serang Banten \\ ${ }^{3}$ Pendidikan Teknologi Informasi Universitas Bina Bangsa Kota Serang Banten \\ beni.junedi@binabangsa.ac.id ${ }^{2}$
}

\begin{abstract}
Abstrak
Tujuan penelitian ini adalah untuk meningkatkan kemampuan pemahaman konsep matematika siswa melalui model pembelajaran kooperatif tipe make a match pada siswa kelas VII SMP Negeri 4 Batang Gansal. Jenis penelitian yang digunakan adalah penelitian tindakan kelas dengan beberapa siklus yang terdiri dari perencanaan, pelaksanaan, observasi dan refleksi pada setiap siklusnya. Instrumen penelitian berupa tes observasi dan pemahaman konsep matematika. Hasil tes pemahaman konsep matematika dianalisis kemudian dibandingkan dengan kriteria ketuntasan minimal (KKM), sedangkan KKM yang ditentukan untuk mata pelajaran matematika adalah 72 . Berdasarkan uji hipotesis penelitian, data hasil pemahaman konsep matematika siswa diperoleh pada pra siklus, siklus I dan siklus II. Dari 43 siswa tersebut, jumlah siswa yang mencapai KKM pada prasiklus sebanyak 22 siswa atau 51,18\%, siklus I sebanyak 24 siswa atau 55,81\%, dan siklus II sebanyak 35 siswa atau 81,40\%. Dengan demikian dapat disimpulkan bahwa terdapat peningkatan kemampuan pemahaman konsep matematika siswa melalui penerapan model pembelajaran kooperatif tipe make a match.

Katakunci: pemahaman konsep matematika, model pembelajaran kooperatif tipe make amatch
\end{abstract}

\begin{abstract}
The aim of the research was to improve students' ability to understand mathematical concepts through cooperative learning model make a match type in class VII SMP Negeri 4 Batang Gansal. The type of research used is classroom action research with several cycles consisting of planning, implementing, observing and reflecting in each cycle. The research instrument was a test of mathematical concept understanding and observation. The results of the mathematical concept understanding test were analyzed and then compared with the minimum completeness criteria (KKM), while the specified KKM for mathematics subjects was 72. Based on the research hypothesis test, data on the results of students' understanding of mathematical concepts were obtained in pre cycle, cycle I and cycle II. Of the 43 students, the number of students who reached the KKM in the pre-cycle was 22 students or $51.18 \%$, in the first cycle there were 24 students or $55.81 \%$, and in the second cycle there were 35 students or $81.40 \%$. Thus it can be concluded that there is an increase in students' ability to understand mathematical concepts through the application of the make a match type of cooperative learning model.
\end{abstract}

Keywords: understanding mathematical concepts, cooperative learning model make a match type

\section{PENDAHULUAN}

Pemahaman konsep merupakan suatu kemahiran atau kecakapan yang diharapkan pada siswa. Kemampuan pemahaman konsep merupakan kemampuan untuk menangkap arti materi pelajaran yang dapat berupa kata, angka, simbol, dan menjelaskan sebab akibat (Permendiknas no 58 Tahun 2014). Kemampuan pemahaman konsep merupakan bagian yang penting di dalam pembelajaran matematika. 
Tujuan pembelajaran matematika yaitu memahami konsep matematika, menjelaskan keterkaitan antar konsep dan mengaplikasikan konsep atau algoritma secara luwes, akurat, efisien dan tepat dalam pemecahan masalah (Permendiknas no 22 tahun 2006). Kemampuan pemahaman konsep matematis yang baik dapat membantu siswa menyelesaikan atau memberikan solusi terhadap suatu permasalahan. Kemampuan tersebut dapat dikembangkan di setiap proses pembelajaran matematika. National Council of Teachers of mathematics (NCTM) Principles and Standards for School Mathematics menyatakan bahwa pemahaman konsep matematis siswa dapat dilihat dari (1) mendeskripsikan konsep dengan kata-kata sendiri, (2) mengidentifikasi atau memberikan contoh dan bukan contoh konsep, (3) menggunakan konsep dengan benar dalam berbagai situasi (Khoiri, 2014). Indikator ini menjadi tolok ukur dalam melihat dan mengembangkan kemampuan matematis siswa di setiap proses pembelajaran matematika.

Pemahaman konsep matematis siswa sangat penting untuk dikembangkan di dalam proses pembelajaran. Namun faktanya di sekolah-sekolah kemampuan pemahaman konsep matematis siswa masih rendah. Permasalahan berupa (1) kurangnya kemampuan siswa dalam menjelaskan secara verbal mengenai konsep yang telah dicapainya. (2) kurangnya kemampuan siswa dalam memberikan contoh kontra dari konsep yang telah dipelajarinya (3) kurangnya kemampuan mengembangkan konsep yang telah dipelajarinya. Berdasarkan beberapa penelitian terdahulu menyatakan bahwa siswa-siswa masih bermasalah dengan pemahaman konsep. Siswa belum bisa mengaplikasikan konsep yang telah diajarkan jika diberikan soal cerita, siswa mengalami kesulitan dalam menyelesaikan soal yang modelnya sedikit berbeda dari contoh dan siswa kurang paham dalam menentukan hal-hal yang diketahui pada soal cerita (Suraji, et al., 2018). Dalam pengerjaan soal yang berkaitan dengan konsep aljabar siswa sering melakukan kesalahan dan siswa belum bisa mengembangkan syarat perlu atau syarat cukup suatu konsep dengan tepat (Kartika, 2018; Hadi \& Kasum, 2015). Dalam mengatasi permasalahan rendahnya kemampuan pemahaman konsep matematis siswa perlu upaya yang dilakukan untuk meningkatkan kemampuan tersebut di setiap proses pembelajaran. Upaya ini dapat dilakukan dengan cara mensinergikan dengan model pembelajaran, salah satunya model pembelajaran kooperatif.

Model pembelajaran kooperatif sangat bervariasi. Model pembelajaran kooperatif tipe make a match dapat mensinergikan kemampuan pemahaman konsep matematis di dalam proses pembelajaran. Keunggulan model pembelajaran kooperatif tipe make a match siswa mencari pasangan sambil belajar mengenai suatu konsep atau topik dengan batas waktu yang ditentukan sehingga siswa dituntut untuk lebih cepat berpikir dalam menemukan kartu pasangan soal dan jawaban (Kusmanto, 2017). Penerapan model pembelajaran dimulai dari siswa mencari pasangan kartu yang merupakan jawaban atau soal sebelum batas waktunya, siswa yang dapat mencocokkan kartunya diberi point (Kusmanto, 2017). Pembelajaran make a match merupakan suatu metode pembelajaran mencari pasangan. Siswa harus mencari pasangan kartu soal yang dimiliki sambil belajar mengenai suatu konsep atau topik dalam suasana yang menyenangkan. Dalam menentukan kartu jawaban siswa dituntut untuk menentukan jawaban atau soal dari kartu yang dipegang (Ubaidah, 2016). Belajar kooperatif tipe make a match (mencari pasangan) yaitu dengan guru menyajikan materi klasikal, terlebih dulu guru memberikan persoalan kepada siswa dengan memberikan sebuah kertas yang berisikan soal atau jawaban di dalamnya dan siswa akan belajar kelompok dengan cara mencari pasangannya untuk mencocokan antara soal dan jawaban yang mereka miliki. Apabila ada kelompok yang paling cepat maka akan diberikan reward (Septian., Maghfirah., \& Sumirah, 2020).

Model pembelajaran kooperatif tipe make a match siswa diajak untuk mencari 
pasangan sambil belajar mengenai suatu konsep atau topik dalam suasana yang menyenangkan. Siswa mencari pasangan dengan bantuan kartu-kartu yang berisi pertanyaan-pertanyaan dan kartu lainnya berisi jawaban dari pertanyaan-pertanyaan tersebut (Sundari, 2017). Model pembelajaran ini lebih efektif digunakan untuk belajar karena siswa diberi kesempatan untuk memahami konsep matematika dari materi yang sedang dipelajari (Ferdiana, et al., 2020). Penerapan model pembelajaran kooperatif tipe make a match dapat menstimulus siswa dalam meningkatkan kemampuan pemahaman konsep matematis nya hal ini disebabkan oleh adanya proses pencocokan pencarian pasangan jawaban dari permasalahan yang diberikan.

Penerapan model pembelajaran kooperatif tipe make a match perlu perencanaan dan persiapan secara baik dan sistematis. Sarana dan prasarana sangat diperlukan dalam mendukung keberhasilan penerapan model pembelajaran ini. Tujuan penelitian untuk meningkatkan kemampuan pemahaman konsep matematis siswa melalui model pembelajaran kooperatif tipe make a match di kelas VII SMP Negeri 4 Batang Gansal.

\section{METODE}

Jenis penelitian yang digunakan merupakan penelitian tindakan kelas. Penelitian tindakan kelas merupakan suatu perencanaan terhadap kegiatan yang sengaja dimunculkan dan terjadi dalam sebuah kelas.Penelitian ini merupakan penelitian kualitatif dengan penelitian tindakan kelas.

Subjek penelitian merupakan siswa kelas VII SMP Negeri 4 Batang Gansal dengan jumlah 43 (empat puluh tiga) siswa. Teknik pengumpulan data dengan menggunakan pengamatan dan tes pemahaman konsep matematis siswa. Instrumen yang digunakan berupa lembar pengamatan yang digunakan untuk mengumpulkan data proses pelaksanaan model pembelajaran kooperatif tipe make a match, soal tes pemahaman konsep matematis siswa yang digunakan untuk melihat kemampuan pemahaman konsep matematis siswa.

Rancangan penelitian terdiri dari beberapa siklus. Setiap siklus dilaksanakan dengan model penelitian Kemmis dan Mc Taggart yang terdiri dari empat komponen perencanaan (planning), tindakan (acting), observasi (observasi) dan refleksi (reflecting) (Fahrudin, et al., 2018). Data dianalisis dengan cara menentukan rata-rata kemampuan pemahaman konsep matematis siswa per tindakan dalam satu siklus. Hal ini dilakukan untuk mengetahui seberapa baik skor siswa secara keseluruhan pada kemampuan pemahaman konsep. Skor ratarata pemahaman konsep matematis siswa diperoleh dari rumus. (Sudjana, 2002: 67).

$$
\begin{aligned}
& \underline{x}=\frac{\sum x}{n} \\
\underline{x} & =\text { Mean (rata-rata) } \\
x & =\text { Skor individual } \\
n & =\text { Jumlah siswa }
\end{aligned}
$$

Sedangkan persentase KKM diperoleh dengan menggunakan rumus: (Sudijono, 2008: 43).

$$
\begin{aligned}
& \quad P=\frac{F}{N} X 100 \% \\
& P=\text { Total persentase kelas } \\
& F=\text { Total persentase skor } \\
& N=\text { Jumlah siswa }
\end{aligned}
$$

Kriteria ketuntasan belajar siswa dalam penelitian dinyatakan sebagai berikut. (a) ketuntasan perorangan, seorang siswa dikatakan tuntas apabila telah mencapai nilai $\geq 72$ dari nilai maksimal 100. (b) ketuntasan klasikal, suatu kelas dikatakan tuntas apabila terdapat minimal $75 \%$ yang telah mencapai nilai $\geq 72$ dari nilai maksimal 100.

\section{HASIL PENELITIAN DAN PEMBAHASAN}

Langkah awal yang dilakukan dalam penelitian adalah melakukan pra-tindakan dalam proses pembelajaran. Selama peneliti melakukan proses pembelajaran, peneliti dinilai oleh observer terkait kegiatan selama 
pembelajaran berlangsung. Berikut hasil pengamatan proses pembelajaran pra siklus dapat dilihat pada Tabel 1.

Tabel 1. Hasil pengamatan proses pembelajaran pra siklus

\begin{tabular}{|l|c|}
\hline \multicolumn{1}{|c|}{ Uraian } & Persentase Keterlaksanaan \\
\hline Keterlaksanaan Pembelajaran & $52,17 \%$ \\
\hline Aktivitas Siswa & $68,75 \%$ \\
\hline
\end{tabular}

Berdasarkan Tabel 1 dapat diketahui bahwa hasil observasi pada kegiatan pra siklus dari 23 item yang di observasi, di ketahui bahwa alternatif jawaban "Ya" 12 item dengan persentase $52,17 \%$, sedangkan alternatif jawaban "Tidak" 11 item dengan persentase $47,83 \%$. Hasil pengamatan aktivitas siswa selama proses pembelajaran berlangsung, berdasarkan tabel 1 dapat diketahui bahwa persentase keterlaksanaan aktivitas siswa sebesar $68,75 \%$, hasil ini dikategorikan rendah. Berdasarkan hasil observasi pada kegiatan pembelajaran belum sesuai dengan yang diharapkan. Setelah kegiatan pembelajaran pra tindakan, peneliti mengadakan tes untuk mengetahui hasil kemampuan pemahaman konsep matematis siswa. Hasil tes pemahaman konsep matematis siswa pada Tabel 2.

Tabel 2. Hasil tes pemahaman konsep matematika siswa pra siklus

\begin{tabular}{|l|c|c|}
\hline \multicolumn{1}{|c|}{ Uraian } & Jumlah Siswa & Persentase \\
\hline Tuntas & 22 siswa & $51,18 \%$ \\
\hline Tidak Tuntas & 21 siswa & $48,82 \%$ \\
\hline
\end{tabular}

Berdasarkan Tabel 2 dapat dilihat bahwa pencapaian hasil tes kemampuan pemahaman konsep matematis siswa masih rendah dilihat dari indikator keberhasilan penelitian. Berdasarkan hasil tes pemahaman konsep matematis siswa pra siklus diketahui 22 siswa atau $51,18 \%$ mendapatkan nilai di atas KKM, sedangkan terdapat 21 siswa atau 48,82\% belum mencapai KKM. Hasil pemahaman konsep matematis siswa belum memuaskan. Berdasarkan hasil pra tindakan baik pelaksanaan pembelajaran maupun hasil tes pemahaman konsep matematis siswa maka perlu dilakukan penelitian tindakan kelas (PTK).
Setelah kegiatan pra tindakan dianalisis dan di refleksi, maka dilanjutkan dengan kegiatan Siklus I yang terdiri dari 4 tahap, yaitu tahap Perencanaan (Planning), Pelaksanaan (Acting), Observasi (Observing), dan Refleksi (Reflecting). Dalam kegiatan Siklus I peneliti dibantu oleh observer untuk mengisi lembar observasi selama kegiatan pembelajaran berlangsung. Data yang diperoleh pada kegiatan ini akan dijadikan sebagai bahan untuk melakukan refleksi. Adapun rekapitulasi lembar observasi dapat dilihat pada Tabel 3.

Tabel 3. Hasil pengamatan proses pembelajaran pada siklus I

\begin{tabular}{|l|c|c|}
\hline \multirow{2}{*}{ Uraian } & \multicolumn{2}{|c|}{ Persentase Keterlaksanaan } \\
\cline { 2 - 3 } & Pertemuan 1 & Pertemuan 2 \\
\hline Keterlaksanaan Proses Pembelajaran & $73,91 \%$ & $78,26 \%$ \\
\hline Aktivitas Siswa & $70,83 \%$ & $93,75 \%$ \\
\hline
\end{tabular}

Berdasarkan Tabel 3 dapat diketahui bahwa, hasil pengamatan dari 23 item aspek yang diamati pada pertemuan pertama, diperoleh jawaban "Ya" 17 item atau 73,91
$\%$ dan jawaban "Tidak" 6 item atau 26,09

$\%$, sedangkan pada pertemuan kedua diperoleh jawaban "Ya" 18 item atau 78,26 $\%$ dan jawaban "Tidak" 5 item atau 21,74 
$\%$. Hal ini menunjukkan bahwa hasil observasi pada kegiatan siklus I belum memuaskan dan belum sesuai dengan indikator keberhasilan yang diharapkan meskipun terjadi peningkatan pada pertemuan kedua. Setelah kegiatan pembelajaran pada siklus I, peneliti merekapitulasi nilai tes pemahaman konsep matematis siswa. Hasil rekapitulasi hasil tes pemahaman konsep matematis siswa pada siklus I dapat dilihat pada Tabel 4.

Tabel 4. Hasil tes pemahaman konsep matematika siswa pada siklus I

\begin{tabular}{|l|c|c|c|c|}
\hline \multicolumn{1}{|c|}{ Uraian } & Pra Siklus & Persentase & Siklus I & Persentase \\
\hline Tuntas & 22 siswa & $51,18 \%$ & 24 siswa & $55,81 \%$ \\
\hline Tidak Tuntas & 21 siswa & $48,82 \%$ & 19 siswa & $44,19 \%$ \\
\hline
\end{tabular}

Berdasarkan Tabel 4 dapat diketahui bahwa pada kegiatan siklus I terjadi peningkatan yakni dari 22 siswa yang tuntas pada kegiatan pra siklus mengalami peningkatan menjadi 24 siswa atau 55,81 $\%$, sedangkan terdapat 19 siswa atau 44,19 $\%$ yang tidak tuntas. Hal ini belum sesuai dengan indikator keberhasilan yang diharapkan walaupun terjadi peningkatan, namun hasil penelitian perlu ditingkatkan menjadi lebih baik. Peneliti dan observer sepakat untuk melakukan perbaikan pembelajaran dan memutuskan untuk melanjutkan pembelajaran pada siklus II dengan harapan dapat mencapai indikator keberhasilan penelitian. Perbaikan yang dilakukan berupa peningkatan aktivitas siswa dengan cara pemberian kartu-kartu yang lebih bervariasi dalam tingkatan item pertanyaan, kemudian setiap kelompok yang berhasil terlebih dahulu menemukan pasangan jawaban diberikan hadiah.

Berdasarkan pengamatan yang dilakukan oleh observer pada kegiatan siklus II terhadap pelaksanaan model pembelajaran kooperatif tipe make a match baik secara langsung maupun melalui lembar observasi dan tes kemampuan pemahaman konsep telah mengalami peningkatan dari sebelumnya. Berikut hasil pengamatan disajikan dalam Tabel 5.

Tabel 5. Hasil pengamatan proses pembelajaran pada siklusII

\begin{tabular}{|l|c|c|}
\hline \multirow{2}{*}{ Uraian } & \multicolumn{2}{c|}{ Persentase Keterlaksanaan } \\
\cline { 2 - 3 } & Pertemuan 1 & Pertemuan 2 \\
\hline Keterlaksanaan Proses Pembelajaran & $86,96 \%$ & $91,30 \%$ \\
\hline Aktivitas Siswa & $95,83 \%$ & $97,92 \%$ \\
\hline
\end{tabular}

Hasil pengamatan siklus II pada pertemuan pertama terlihat semua aspek yang diamati dari 23 item observasi sudah sangat baik yaitu dengan jawaban "Ya" 20 item atau 86,96\% dan jawaban "Tidak" 3 item atau 13,04 \%, sedangkan pada pertemuan kedua dari 23 item yang diamati diperoleh jawaban "Ya" 21 item atau 91,30 $\%$ dan jawaban "Tidak" 2 item atau 8,70\%.
Setelah pelaksanaan tindakan dilakukan dan peneliti telah menemukan keberhasilan dalam kegiatan siklus II dalam lembar observasi kegiatan siswa, kemudian siswa diberi tes kemampuan pemahaman konsep matematis. Hasil tes kemampuan pemahaman konsep matematis siswa dapat dilihat pada Tabel 6 .

Tabel 6. Hasil tes pemahaman konsep matematika siswa pada siklusII

\begin{tabular}{|l|c|c|c|c|}
\hline \multicolumn{1}{|c|}{ Uraian } & Siklus I & Persentase & Siklus II & Persentase \\
\hline Tuntas & 24 siswa & $55,81 \%$ & 35 siswa & $81,40 \%$ \\
\hline Tidak Tuntas & 19 siswa & $49,19 \%$ & 8 siswa & $18,60 \%$ \\
\hline
\end{tabular}

Berdasarkan analisis data pada siklus II sesuai dengan Tabel 6 dapat dilihat bahwa mengalami peningkatan yang signifikan terhadap kemampuan pemahaman konsep 
matematika siswa dari pra siklus 51,18\% siswa yang tuntas dan pada siklus I 55,81\% yang tuntas, namun pada akhir siklus II ini siswa mengalami peningkatan dan mencapai KKM yaitu sebesar 81,40 \% siswa tuntas.

Dengan penerapan model pembelajaran kooperatif make a match pembelajaran menjadi menyenangkan, suasana pembelajaran menjadi aktif, dan pemberian materi dapat menarik perhatian siswa. Penerapan pembelajaran ini dapat menumbuhkan sifat kerjasama dan saling membantu sehingga tujuan pembelajaran tercapai dengan baik. Dalam pelaksanaanya pemberian hadiah menjadikan siswa lebih termotivasi untuk menemukan jawaban atas kartu pertanyaan yang disediakan oleh guru sehingga setiap kelompok berlomba-lomba untuk mendapatkan hadiah tersebut.

Dengan adanya proses dan aktivitas pembelajaran yang baik sehingga memberikan dampak penerapan model pembelajaran kooperatif make amatchdapat meningkatkan kemampuan pemahaman konsep matematis siswa di SMP Negeri 4 Batang Gansal.

\section{SIMPULAN}

Berdasarkan penelitian yang telah dilaksanakan dapat disimpulkan bahwa terdapat peningkatan kemampuan pemahaman konsep matematis siswa melalui model pembelajaran kooperatif tipe make a match di kelas VII SMP Negeri 4 Batang Gansal.

\section{REFERENSI}

Fahrudin, A. G., Zuliana, E., \& Bintoro, H. S. (2018). Peningkatan Pemahaman Konsep Matematika Melalui Realistic Mathematic Education Berbantu Alat Peraga BONGPAS. Anargya: Jurnal Ilmiah Pendidikan Matematika, 1(1), 14-20.

Ferdiana, V., Mulyatna, F. (2020). Pengaruh Model Pembelajaran Kooperatif Tipe Make a Match terhadap Pemahaman Konsep Matematika Siswa. In: SINASIS (Seminar Nasional Sains).

Hadi, S., \& Kasum, M. U. (2015). Pemahaman konsep matematika siswa SMP melalui penerapan model pembelajaran kooperatif tipe memeriksa berpasangan (Pair Checks). Edu-Mat: Jurnal Pendidikan Matematika, 3(1).

Kartika, Y. (2018). Analisis kemampuan pemahaman konsep matematis peserta didik kelas vii smp pada materi bentuk aljabar. Jurnal Pendidikan Tambusai, 2(2), 777-785.

Khoiri, M. (2014, November). Pemahaman siswa pada konsep segiempat berdasarkan teori van Hiele. In Prosiding Seminar Nasional Matematika, Universitas Jember (Vol. 19).

Kusmanto, H. (2017). Pengaruh Penerapan Model Pembelajaran Kooperatif Tipe Make A Match terhadap Kreativitas Siswa dalam Pembelajaran Matematika. Eduma: Mathematics Education Learning and Teaching, 6(1), 32-42.

Peraturan Menteri Pendidikan dan Kebudayaan. (2014). Peraturan Menteri Pendidikan dan Kebudayaan Republik Indonesia Nomor 58 Tahun 2014 tentang Kurikulum 2013 Sekolah Menengah

Pertama/Tsanawiyah. Jakarta:

Kementerian Pendidikan dan Kebudayaan Republik Indonesia.

Peraturan Menteri Pendidikan Nasional Nomor 22 tahun 2006 tentang Standar Proses Isi. (2006). Jakarta: Depdiknas

Septian, A., Maghfirah, D., \& Sumirah, A. (2020). Peningkatan Kemampuan Komunikasi Matematis Siswa dengan Model Pembelajaran Kooperatif Tipe Make A Match. Pasundan Journal of Mathematics Education Jurnal Pendidikan Matematika, 10(1), 66-77.

Sudijono, A. (2008). Pengantar Statistika Pendidikan. Rajawali : Jakarta

Sudjana. (2002). Metode Statistika. Tarsito : Bandung

Sundari, J. (2017). Pengaruh Model Pembelajaran Kooperatif tipe Make A Match terhadap Kemampuan Komunikasi Matematis Siswa. JKPM (Jurnal Kajian Pendidikan Matematika), 2(2), 227-234.

Suraji, S., Maimunah, M., \& Saragih, S. (2018). Analisis kemampuan pemahaman konsep matematis dan 
kemampuan pemecahan masalah matematis siswa smp pada materi sistem persamaan linear dua variabel (SPLDV). Suska Journal of Mathematics Education, 4(1), 9-16.

Ubaidah, N. (2016). Pemanfaatan CD pembelajaran untuk meningkatkan kemampuan komunikasi matematis siswa melalui pembelajaran make a match. Jurnal Pendidikan Matematika FKIP Unissula, 4(1), 53-70. 